\title{
The Relationship between the Quality of Life and Hope with Depression among Divorced Women and Divorce Applicant
}

\author{
Mostafa Tavakol, Alireza Heidarei \\ Islamic Azad University of Ahvaz Branch, Ahvaz, Iran \\ E-mail address: mostafa_khan74@yahoo.com
}

Keywords: depression, Hope to life, divorced women, and divorce applicant, life quality.

ABSTRACT. The aim of this current study is to identify the relation of hope and the quality of life with depression in divorced women and those who want to get divorce in Ahvaz City. The population of this study include all of the women who referred to the Family Divorce court Ahvaz City in 2014.

The population of the number of divorce cases was 125 people and 191 available widow were selected in available sampling method and the total number of them were 316 person.

The tools which were applied in this study consist of miller hope scale (1988), the world health organization quality of life questionnaire summary (1998) and beck depression questionnaire (1978).

The study design was correlation that the obtained results based on correlation and regression analysis shows the $\mathrm{a}=0.001$ and there is a relationship.

Between Hope life and qualify of life with depression among divorced women and divorce applicant in Ahvaz City.

\section{INTRODUCTION}

Divorce is a phenomenon that has psychological, social and economic consequences. Psychological dimension has special importance. Divorced person are encountered numerous interpersonal and personal conflicts such that they experience disturbed identity, the lack of hope, change in life style, serious problems in social and career network. Depression is one of the results of divorce and depression is the most wide spread mental disorders in widow (liker et.al 2014).

Sligman (1990) called depression an a mental cold because it spreads a lot. In fact, depression is a pervasive illness and it hurts person's soul Sense of the absurd and discomfort, frustration and negative thoughts a depressed person has a slow behavior and he is usually deprived from routine activity and pleasant feelings and he is experienced some troubled times in some periods of his life.

Stressors after divorce cannot be considered apart from features such as self - confidence, self - esteem, optimism and hope, as well as economic prosperity, social acceptance and quality of life. In roger's opinion, Pattenden, Pullen \& Bickerdike (2010), one of the reasons of depressed widow are the low quality of life, welfare and economic social, status the results show that there is a reverse relation between depression levels, stress with the quality of life and reversely, there is a positive relation among the high quality of life and self- valuable, positive thought, physical health and social - psychological relations (Newton, Ryan, King \& Smith, 2014, Mendes, 2013, Taheri and Amiri, 2010, kejbaf et al, 2011).

On the other hand, in snyder's (2001) opinion, hope is an emotional power that move the imagination to positive things. Hope gives energy to humans and equip them and it acts as catalyst for work and activity. Hope imposes flexibility, exhilaration and the ability to get ride of life damages hose increases the life satisfaction.

Hopefulness is a connection between behaviors related with aim and person's belief to achieve this aims. Hope theory is a cognitive theory that individuals follow their goals actively. George (2010) shows in his study under (the sense of well - being in late life) that life satisfaction increases the hope and happiness in last years of life. Therefore, in relation with the studies on divorce and it's 
psychological consequences, we attempt to focus on the relationship between the quality of life and hope to the future with depression among widow women and those who want to get divorce.

\section{RESEARCH METHOD}

Population, sample and sampling:

The population of this study include all of those women the population of this study include all of those women who want to get divorce in Ahvaz city that they had referred to the family court and also include all of the widow women in Ahvaz city whose their age in below 40 years and they have spent 5 years after their divorce. From the mentioned community, 316 person were selected as study sample by using available sampling method.

Research tools:

Miller hope scale: Miller Hope Questionnaire (1988) consists of 48 items which it is codified based on 5 spectrum point Likert and it is grading on very disagree (1) to very agree (5). Hope scale scores range are between 48 to 240 which represent the high person hopefully and low scores show the lack of hope in person. Mortezaie (2010) integrated the Malaki reliability method with symptom's scale hope in the field of adult (1992). The correlation between these two measure expectancy was $\% 89$ that indicate the high validity of this scale. Hope scale reliability was obtained respectively $88 \%$ and $89 \%$ by using Cronbach's alpha and compilation method.

Quality of Life scale: Quality of life questionnaire of health world organization (1998) includes 26 question and it measures 4 area of physical health, mental health, social relations and environment health and it has 24 question. (Every area has 7,3,6 and 8 question). Two questions don't belong to none of the area, and they evaluate health status and quality of life. All of questions have 5 options and liker scale that the fifth option represent the best position (score 4) and the first option is indicative of the worst position (score zero). In the current study, quality life reliability coefficient was obtained by Cronbach's Alpha and compilation method and they were respectively $91 \%$ and $85 \%$.

Depression questionnaire: Beck's depression questionnaire (1978) has two form of 21 and 13 question that we used the short from of them in this study. Every proposition includes a multiple choice scale which it's domain in from zero to there.

Therefore, the minimum score and the maximum score are respectively zero and thirtynine that high scores show the high depression and low score indicate the lack of depression or low depression. Munaf and Siddiqui (2013) report Beck's depression questionnaire reliability coefficient by using Cronbach's alpha and bisection method and they were respectively $\% 81$ and $\% 72$.

\section{FINDINGS}

Table 1 shows the index related to descriptive statistics and it include average, standard deviation, the minimum score and the maximum score for the examined variable in this study.

Table 1: Shows the index related to descriptive statistics

\begin{tabular}{|c|cccc|}
\hline $\begin{array}{c}\text { statistical Indexes } \\
\text { variable }\end{array}$ & mean & Standard deviation & minimum & maximum \\
\hline depression & 22.62 & 7.59 & 4 & 34 \\
hope & 99.92 & 30.06 & 52 & 173 \\
quality of life & 47.71 & 17.05 & 17 & 95 \\
\hline
\end{tabular}

As you have seen in table 1, average and standard deviation of depression scale are respectively 99.92, 7.59 and hope scales are 99.2, 30.06 and quality of life scales are 47.71 and 17.05. 
First hypothesis: there is a relationship between hope and widow women depression and those who want to get divorce.

Table 2: Pearson correlation coefficient between hope and depression

\begin{tabular}{|c|c|c|c|}
\hline $\begin{array}{c}\text { Statistical indexes } \\
\text { variable }\end{array}$ & $\begin{array}{c}\text { Correlation } \\
\text { coefficient }\end{array}$ & $\begin{array}{c}\text { Coefficient of } \\
\text { determination }\end{array}$ & significant \\
\hline $\begin{array}{c}\text { Hope and } \\
\text { depression }\end{array}$ & -0.42 & 0.18 & 0.001 \\
\hline
\end{tabular}

As you see in the table 2 , the Pearson correlation coefficient between hope and depression among widow women and divorce applicant is $(\mathrm{r}=-0.42)$ so that is a significant and negative relation between these variables.

Second hypothesis: there is a relationship between quality of life and depression of widow women and divorce applicant.

Table 3: Pearson correlation coefficient between quality of life and depression

\begin{tabular}{|c|c|c|c|}
\hline $\begin{array}{c}\text { Statistical indexes } \\
\text { variable }\end{array}$ & $\begin{array}{c}\text { Correlation } \\
\text { coefficient }\end{array}$ & $\begin{array}{c}\text { Coefficient of } \\
\text { determination }\end{array}$ & significant \\
\hline $\begin{array}{c}\text { Quality of life and } \\
\text { depression }\end{array}$ & -0.51 & 0.26 & 0.001 \\
\hline
\end{tabular}

As you see in the table 3 , the Pearson correlation coefficient between quality of life and depression among widow women and divorce applicant is $(\mathrm{r}=-0.42)$ so that is a significant and negative relation between these variables.

Third hypothesis: there is a multiple relationship between hope and quality of life with depression of widow women and divorce applicant.

Table 4: Multiple correlation between hope and quality of life with depression

\begin{tabular}{|c|c|c|c|c|c|c|}
\hline $\begin{array}{c}\text { Statistical indexes } \\
\text { variable }\end{array}$ & $\begin{array}{c}\text { Multiple } \\
\text { correlation }\end{array}$ & $\begin{array}{c}\text { Coefficient of } \\
\text { determination }\end{array}$ & $\mathrm{B}$ & $\beta$ & $\mathrm{t}$ & significant \\
\cline { 1 - 5 } Quality of life & \multirow{2}{*}{$0 / 59$} & $0 / 34$ & $-0 / 402$ & -0.388 & -3.08 & 0.01 \\
\cline { 1 - 5 } \cline { 4 - 7 } hope & $0 / 34$ & -1.54 & -1.12 & -7.04 & 0.01 \\
\hline
\end{tabular}

As you see in the table 4, based on the results obtained from multiple regression analysis and by con current entrance method, multiple correlation coefficient for the linear mixture of hope and quality of life with depression among widow women and divorce applicant correspond to $\mathrm{MR}=0.59$ and determination coefficient is equal to $\mathrm{RS}=0.34$ that the of hop to future in level $(p<0.01)$, quality of lifeeffect, physical health and mental health in level $(\mathrm{p}<0.001)$ and social performance effect and environmental health in level $(p<0.05)$ are significant. According to the obtained determination coefficient, it is obvious that depression variance is $34 \%$.

\section{DISCUSSION AND CONCLUSION}

It is confirmed the first hypothesis as a significant relation between hope to future and depression and this result are consistent with Rashidyan (2012), Chang et al (2013) and Mathew et al (2014) study.

It can be judged that in Snyder's opinion (2000), individual with high level of hope can protect themselves against depression and they can be improved from depression in short period and there is less possible that they experience the depression again. Research's show that the depression symptoms and stress in hopeful persons will be reported lesser. Low hope can predict depression level and social - psychological faults. 
Mathew et al (2014) expresses that hopeful ness is as the recovery target for individual life that they suffer from depression and stress, Because when physical damage is caused, hopefulness change the available status will be encounter with failure. Hopefulness helps persons to get philosophy of life based on their decisions and fate. In fact, hopefulness in the biggest weapon to overturn persons experience from depression after the negative life occurrences.

Beck (2000) expresses the hopelessness as the main symptom of depression and he says that hopelessness destroys the will and it causes insufferable position.

Studies are focuses on negative events such as divorces, death of the parents and incurable illness that may have a hopelessness advancement.

Hypothesis 2 as the relationship between quality of life with depression confirms that this findings are consistent with Haghgou et al (2009), Mendes (2013), Newton et al (2014) results. It can be stated that divorce is not the ending part of marriage stresses but some events and consequences are caused in tho last periods of marriage and they can influence life quality, behavior, widow woman health and emotions. This mediators include the care responsibilies'schildren, cut off communication with children (among widow women who are deprived of maintain children). Keep on conflict with the former wife, meet the child. The lack of emotional support because of reduction is casual relatives, reduced economic activity and some disturbed routine events like moving form suitable and the most expensive environment to the poor neighborhood and inadequate living facilities this effective factors on quality of life offer some mechanism that because of them, divorce on mental health, individual performance, life level and psychological welfare will have negative effects. In such circumstances, the possibility of the person gets involved in mood and emotion disorders is very high (Newton, 2014).

Hypothesis 3 which is the main hypothesis, it is confirmed as a multiple relationship existence between hope and qualify of life with depression significance in widow women and divorce applicant.

The current research result are consistent with Rashidyan (2012), Mendes (2013), Chang et al (2013) and Newton et al (2013) research results.

Strong and significant role in explaining depression future prediction and quality of life. For divorced women and divorce applicant, it can be concluded that hope to life as a psychological characteristics of individuals has a significant effect on sense of responsibility, future's goal, selfefficacy, development motivation and psychological disorders suchas depression and stress. On the other hand, it is emphasized on quality of lifeas one of the social - individual variables and it affects on four components which IE includes two aspects of individuals and two social aspects. It means that two aspects of mental health and physical health pertaining to individual's components and environmental health and social performance are related to social space friend's network and colleagues. So it can be expected because widow women and divorced applicant don't have suitable quality of lifeand hope to the future, they suffer from depression and this two variable can explain depression significantly.

\section{Reference:}

[1] Agha Bagheri, H., Mohammad khani, P., Omrani, S., \& Farahmand, W. (2012). The effectiveness of cognitive therapy group based on immediacy on mental welfare improvement and hope to MS patients. Clinical psychological journal, 4(1), 23 - 31.

[2] Bahrami, F., Sodani, M., \& MehrabiZade, M. (2009). Effectiveness of Gestalt therapy on selfesteem, depression and depressed widow women feeling. Journal of Social-psychological studies women, 8(1), 129-145.

[3] Beck, J. (2000). Cognitive Therapy: Basics and Beyond. New York: Guilford Press 
[4] Benson, W. (2006). The role of hope and study skills in predicting test anxiety level of university students highschool and psychological health, self-esteem, positive thinking and social communication. These is for degree of master of science in the department of educational sciences middle east technical university.

[5] Chang, E. C., Yu, E. A., \& Hirsch, J. K. (2013). On the confluence of optimism and hope on depressive symptoms in primary care patients: Does doubling up on bonum futurun Proffer any added benefits? Journal of Positive Psychology, 8(5), 404-411.

[6] Di Marco, S., Gambaro, E., Zeppegno, P., \& Gramaglia, C. (2013). Postpartum depression, anxiety and marital relationship: A pilot study. European Psychiatry, 28 (1) 1.

[7] Faso, D. J., Neal-Beevers, R., Carlson, C. L. (2013). Vicarious futurity, hope, and well-being in parents of children with autism spectrum disorder. Research in Autism Spectrum Disorders, Volume 7(2), 288-297.

[8] George, L. K., (2010). Still happy after all these years: Research frontiers on subjective wellbeingin Later Life. Journal of Gerontology: Social sciences. 65 (3). 331-339.

[9] Haghgoo, H., SaedPazooki, E., Sarafraz, Z., \& Rasafyani, M. (2009). The study of relationship between depression and quality of life in patients with stroke.

[10] Jenkins, P. E., Hoste, R. R., Meyer, C., \& Blissett, J. M. (2011). Eating disorders and quality of life: A review of the literature. Clinical Psychology Review 31, 113121.

[11] Kajbaf, M. B., Aghaie, A., \& Mohmood, E. (2010). The study of happiness education effect on qualify of life for couples who refer to Esfahan consultation centers. journal of family research, $7(1), 69-81$.

[12] Lau, Y., Yin, L. (2011). Maternal, obstetric variables, perceived stress and health-related quality of life among pregnant women in Macao, China. Midwifery, 27, 5, 668-673.

[13] Liker, A., Freckleton, R. P., \& Székely, T. (2014). Divorce and Infidelity Are Associated with Skewed Adult Sex Ratios in Birds. Current Biology, 24, 8, 880-884.

[14] Marnat, G. (1990). Hand book of psychological assessment, for clinical psychologist, advisors and psychiatrists, pasha Hassan and Mohammad Reza Nikkhan Translation (2010). Tehran, Roshd Publication.

[15] Mathew, J., Dunning, C., Coats, C., \& Whelan, T. (2014). The mediating influence of hope on multidimensional perfectionism and depression. Personality and Individual Differences, 70, 6671.

[16] Mendes, M. S. (2013). Depression and women's life cycle:comparative prevalence of depressive symptons in women along the life cycle in a portuguese community sample European Psychiatry, 28, 1, 1 .

[17] Mortezaie, A. (1390). Logo therapy effect on depression, sleep quality and hope fullness in women with breast cancer in Sanandaj city. MA Thesis clinical psychological, Tehran University.

[18] Munaf, S., \& Siddiqui. B. (2013). Relationship of Post-natal Depression with Life and Marital Satisfaction and Its Comparison in Joint and Nuclear Family System. Procedia - Social and Behavioral Sciences, 84, 9,733-738.

[19] Newton, N. J, Ryan, L. H., King, R. T., \& Smith, J. (2014). Cohort differences in the marriage-health relationship for midlife women. Social Science \& Medicine, 116, 64-72.

[20] Rajandram, R. K., Ho, S. M., Samman, N., Chan, N., McGrath, C., \& Zwahlen, R. A. (2011). Interaction of hope and optimism with anxiety and depression in a specific group of cancer survivors: a preliminary study. Journal of BMC Research Notes, 2, 1-7. 
[21] Rashidyan, H. (2012). The examination of the relationship between confrontation ways with stress, happiness and hope with depressed widow women and 30 years in Kermanshah city. MA thesis family consultation.

[22] Psychological college and pedagogical science, Tehran universityRogers, M., Pattenden, R., Pullen, P., \& Bickerdike, A (2010). Women and separation: Managing new horizons. Relationships Australia (Victoria) and beyondblue: the national depression initiative.

[23] Snyder, C. R,. \& Lopez, S. J. (2001). Handbook of Positive Psychology. US: Oxford University Press.

[24] Snyder, C.R. (2000). Handbook of Hope, Orlando FL, Academic Press.

[25] Taheri, R., \& Amiri, J. (2009). The effectiveness of education intervention based on models in upgrade marriage. The journal of clinical psychological. 2(3), 25 - 37.

[26] Wong, N., Sarver, D. E. \& Beidel, D. C. (2012). Quality of life impairments among adults with social phobia: The impact of subtype. Journal of Anxiety Disorders ,26, 50- 57. 